\title{
KUALITAS SPERMATOZOA KAMBING BOERAWA DAN KAMBING KACANG PADA PENGGUNAAN TRIS-KUNING TELUR YANG BERBEDA
}

\author{
Rahmiyanti Ismet Inonie ${ }^{1}$, La Ode Baa ${ }^{2}$, Takdir Saili ${ }^{2}$ \\ ${ }^{1)}$ Alumnus Fakultas Peternakan UHO \\ ${ }^{2)}$ Staf Pengajar Fakultas Peternakan UHO
}

\begin{abstract}
ABSTRAK
Penelitian ini bertujuan untuk mengkaji pengaruh interaksi antara bangsa kambing dan konsentrasi pengencer Tris-Kuning Telur terhadap kualitas spermatozoa. Penelitian ini menggunakan Rancangan Acak Lengkap (RAL) Pola Faktorial dengan 2 faktor x 4 perlakuan dengan 4 ulangan. Faktor pertama adalah jenis kambing, yaitu kambing Kacang (K1) dan kambing Burawa (K2) sedang Faktor kedua adalah pengencer Tris-Kuning Telur yang terdiri atas 4 (empat) konsentrasi kuning telur yang berbeda yaitu 5\% (P1), 10\% (P2), 15\% (P3) dan 20\% (P4). Parameter yang diukur adalah evaluasi kualitas semen segar secara makroskopis kambing Burawa dan kambing Kacang terdiri atas : volume, warna, bau dan derajat keasaman $(\mathrm{pH})$ dan secara mikroskopis terdiri atas : gerak massa, konsentrasi, persentase spermatozoa hidup, persentase motilitas dan persentase membran plasma utuh. Hasil penelitian menunjukan karakteristik semen segar kambing Boerawa dan kambing Kacang kualitasnya hampir sama. Interaksi perlakuan bangsa kambing dan konsentrasi pengencer Tris-Kuning Telur tidak berpengaruh nyata terhadap kualitas spermatozoa kambing.Faktor konsentrasi pengencer Tris-Kuning Telur secara mandiri tidak berpengaruh nyata terhadap kualitas spermatozoa kambing. Rataan persentase membran plasma utuh spermatozoa kambing Kacang nyata lebih baik dibandingkan kambing Boerawa setelah pengenceran. Penurunan persentase motilitas spermatozoa selama 4 hari penyimpanan pada suhu $3-5^{\circ} \mathrm{C}$ lebih rendah pada kambing Kacang dibandingkan pada kambing Boerawa. Konsentrasi pengencer Tris-Kuning Telur 10\% mampu mempertahankan motilitas spermatozoa kambing lebih baik dibandingkan konsentrasi pengencer yang lain,konsentrasi pengencer Tris-Kuning Telur $15 \%$ mampu mempertahankan persentase MPU spermatozoa dibandingkan konsentrasi yang lain selama 4 hari penyimpanan pada suhu $3-5^{\circ} \mathrm{C}$.
\end{abstract}

Kata kunci : Kualitas spermatozoa, kambing Burawa, kambing Kacang, pengencer TRIS.

\begin{abstract}
This research was aimed to investigate interaction effect of goat breed and concentration of Tris-yolk diluents on spermatozoa quality. This study was using completely randomized design with factorial pattern 2 factors $\mathrm{x} 4$ treatments with 4 repetitions. First factor was type of goat, that is Kacang goat (K1) and Boerawa goat (K2). Second factor was Tris-yolk diluents consist of 4 different concentration of yolk, that is $5 \%(\mathrm{P} 1), 10 \%(\mathrm{P} 2), 15 \%(\mathrm{P} 3)$, and $20 \%(\mathrm{P} 4)$. Parameters observed were macroscopic evaluation of cement quality of Boerawa and Kacang goat consist of volume, color, odor, and acidity $(\mathrm{pH})$, and by microscopic evaluation consist of mass motion, concentration, percentage of living spermatozoa, motility, and intact plasma membrane. Result of this research showed that cement characteristic of Boerawa and Kacang goat has similar quality. Treatment interaction of goat breed and diluents concentration of Tris-yolk has no real effect on spermatozoa quality of goat. Factor of diluents Tris-yolk concentration itself has no real effect on quality of goat spermatozoa. The average of intact plasma membrane of Kacang goat cement was better be compared with Boerawa goat after dilution. Reduction of spermatozoa motility percentage for 4 days storage at $3-5^{\circ} \mathrm{C}$ was lower on Kacang goat be compared with on Boerawa goat. Concentration of Tris-yolk diluents $10 \%$ could keep spermatozoa motility of goat better than other concentration of diluents. Concentration of Tris-yolk diluents $15 \%$ could keep percentage of spermatozoa MPU than other concentration for 4 days storage at $3-5^{\circ} \mathrm{C}$ of temperature.
\end{abstract}

Key words: spermatozoa quality, Boerawa goat, Kacang goat, and Tris diluents 


\section{PENDAHULUAN}

Kambing atau sering dikenal sebagai ternak ruminansia kecil merupakan ternak herbivora yang sangat populer di kalangan petani. Menurut data statistik peternakan dan kesehatan hewan tahun 2015 (Dirjen $\mathrm{PKH}, 2015)$, populasi ternak kambing di Indonesia sampai dengan tahun 2015 tercatat sebanyak 18.880.000 ekor. Angka tersebut mengalami peningkatan sebanyak 1.934 .000 ekor atau (2.85\% per tahun) sejak tahun 2011 yang hanya berjumlah 16.946.000 ekor. Perkembangan populasi kambing nasional tersebut juga mirip dengan kondisi populasi ternak kambing di Sulawesi Tenggara. Berdasarkan data statistik peternakan dan kesehatan hewan tahun 2015, populasi ternak kambing di Sulawesi Tenggara pada tahun 2015 sebanyak 144.383 ekor, sedangkan populasi ternak kambing pada tahun 2011 hanya berjumlah 124.113 ekor atau meningkat sebesar $4,1 \%$ per tahun (Dirjen PKH, 2015). Hal ini menunjukkan bahwa rataan perkembangan populasi ternak kambing di Sulawesi Tenggara masih lebih tinggi dibandingkan dengan perkembangan populasi ternak kambing secara nasional. Namun demikian, potensi wilayah yang ada di Sulawesi Tenggara masih mengindikasikan belum optimalnya pemanfaatan lahan untuk produksi ternak kambing. Oleh karena itu, peluang peningkatan populasi dan produktivitas ternak kambing masih terbuka lebar melalui perbaikan sistem pemeliharaan dan penerapan bioteknologi, khususnya bioteknologi reproduksi.

Salah satu upaya yang dapat dilakukan untuk meningkatkan populasi dan produktivitas ternak kambing di Sulawesi Tenggara adalah dengan menerapkan metode kawin silang menggunakan jenis kambing yang telah terbukti mempunyai produktivitas tinggi, seperti kambing Boerawa. Pamungkas dkk. (2008) menyatakan bahwa kambing Boerawa merupakan kambing tipe pedaging yang baik dengan bobot lahir $3-4$ $\mathrm{kg}$ dan laju pertambahan bobot badan harian sekitar 140-250 g/hari/ekor. Walaupun kambing Boerawa mempunyai produktivitas yang tinggi, akan tetapi kambing Boerawa mempunyai sisi kelemahan dalam proses perkawinan dengan kambing kacang. Postur kambing kacang yang relatif kecil dibandingkan dengan kambing Boerawa menyebabkan sulitnya melakukan kawin alam pada kedua jenis kambing ini, sehingga kawin dengan menggunakan metode inseminasi buatan (IB) merupakan satu pilihan yang harus ditempuh.

Teknologi IB diharapkan mampu mengoptimalkan penggunaan semen karena semen dari seekor pejantan dapat digunakan untuk mengawini lebih banyak betina. Program IB akan berhasil dengan baik apabila spermatozoa diproduksi dalam jumlah dan kualitas yang baik (Toelihere, 1993). Program IB dapat berkembang, diperlukan semen beku sehingga semen yang berasal dari pejantan-pejantan unggul dapat disimpan dalam waktu yang lama dan didistribusikan ke berbagai wilayah (Amalia, 2002). Namun di lain pihak, penerapan teknologi IB dengan menggunakan semen beku pada kambing belum menunjukkan hasil yang memuaskan. Salah satu penyebab rendahnya angka kebuntingan kambing pada program IB adalah rendahnya kualitas semen beku yang digunakan (Alawiyah dan Hartono, 2006).

Semen yang digunakan pada program IB dapat berupa semen cair atau semen beku. Proses produksi semen cair dan semen beku merupakan hal yang sangat kritis untuk mendapatkan spermatozoa dengan kualitas yang masih memenuhi standar untuk pelaksanaan IB. Salah satu faktor yang menentukan di dalam proses produksi semen cair dan beku adalah pemilihan pengencer yang tepat.

Pengenceran semen merupakan salah satu tahap yang penting dalam prosedur pengemasan semen beku. Syarat penting yang harus dimiliki pengencer yang baik yaitu (1) murah, sederhana, praktis dan mempunyai daya preservasi yang tinggi, (2) mengandung unsur-unsur yang hampir sama sifat fisik dan kimiawinya dengan semen, dan (3) dapat mempertahankan dan tidak membatasi daya spermatozoa. 


\section{METODE PENELITIAN}

\section{A. Waktu dan Tempat}

Penelitian ini dilaksanakan selama 4 (empat) bulan di Laboratorium Unit Pelaksanaan Teknis Daerah (UPTD) Perbibitan Ternak dan Pakan Ternak, Dinas Pertanian dan Peternakan Provinsi Sulawesi Tenggara yang berlokasi di Desa Morome, Kecamatan Konda, Kabupaten Konawe Selatan.

\section{B. Materi Penelitian}

Materi penelitian yang digunakan pada penelitian ini terdiri atas semen dan pengencer Tris-kuning telur. Semen diperoleh dari 5 ekor kambing berumur 1-3 tahun terdiri atas 1 ekor kambing betina sebagai pemancing, dan 4 ekor kambing jantan masing-masing 2 ekor kambing Kacang dan 2 ekor Boerawa. Semua kambing dipelihara di Laboratorium Unit Pelaksanaan Teknis Daerah (UPTD) Perbibitan dan Pakan Ternak Dinas Pertanian dan Peternakan Provinsi Sulawesi
Tenggara. Bahan pengencer semen yang digunakan adalah pengencer Tris Kuning Telur.

Alat yang digunakan pada penelitian ini yaitu mikroskop, vagina buatan, mikropipet, haemocytometer, kertas indikator $\mathrm{pH}$, water bath, lemari es, gelas enlemeyer, gelas ukur, gelas objek, gelas penutup, spoit, tissue, lampu bunsen, dan alat tulis.

\section{Desain Penelitian}

Desain percobaan yang digunakan adalah Rancangan Acak Lengkap Pola Faktorial 2 x 4 dengan 4 ulangan. Faktor pertama adalah jenis kambing, yaitu kambing Boerawa (K1) dan kambing Kacang (K2), sedangkan faktor kedua adalah pengencer Tris-Kuning Telur yang terdiri atas 4 (empat) konsentrasi kuning telur yang berbeda, yaitu 5\% (P1), 10\% (P2), 15\% (P3), dan $20 \%$ (P4). Ringkasan struktur data penelitian ini dapat dilihat pada Tabel 2.

Tabel 2. Kombinasi Perlakuan Jenis Ternak dan Bahan Pengencer

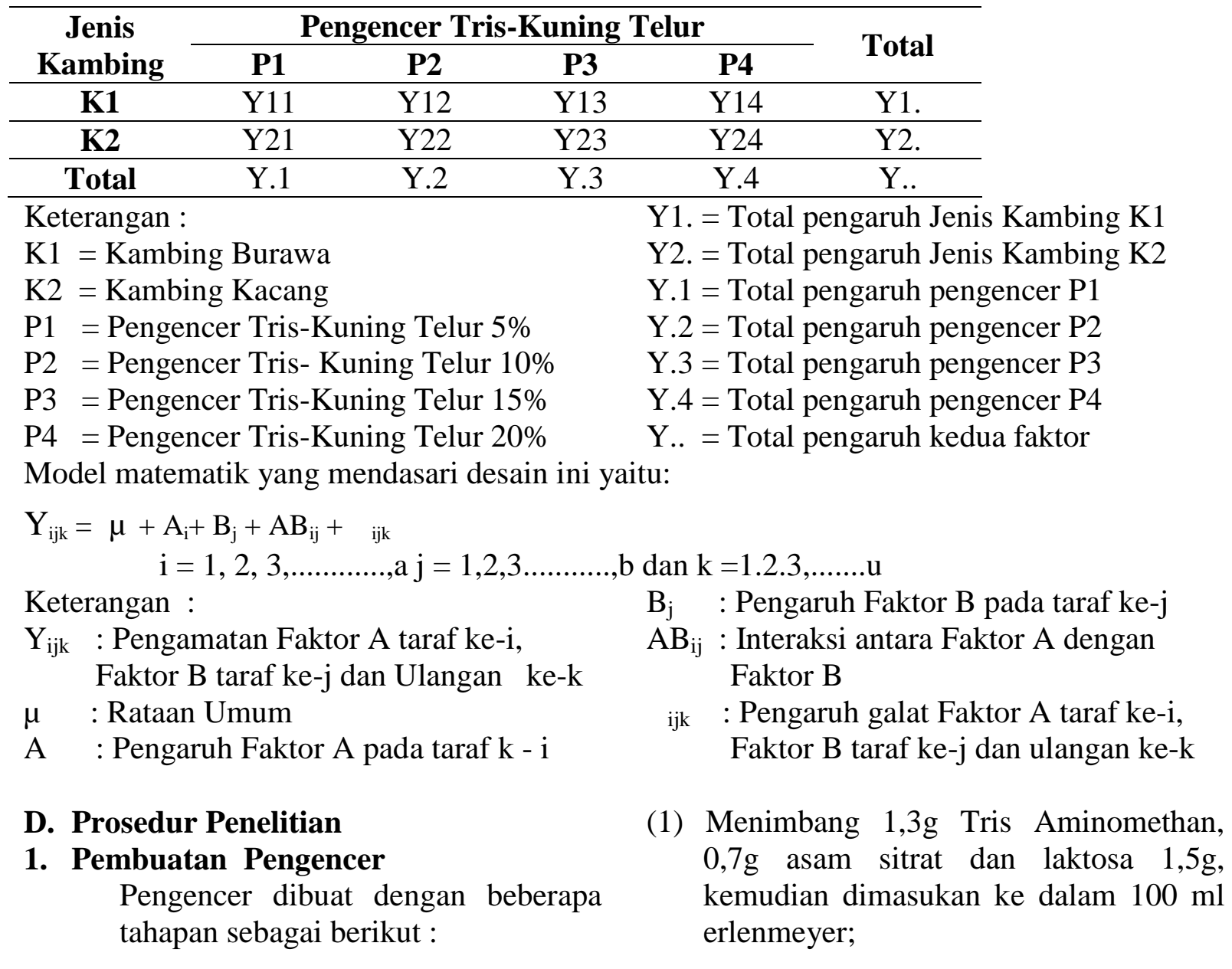


(2) Tambahkan ke dalam erlenmeyer fruktosa dan kuning telur sesuai perlakuan masing-masing secara terpisah, kemudian tambahkan dengan aquades steril $80 \mathrm{ml}$ ke dalam masingmasing perlakuan lalu dihomogenkan dengan magnetic stirer selama 5 menit;

(3) Gelas erlenmeyer yang berisi kuning telur dan fruktosa, laktosa (sesuai perlakuan) dimasukan ke dalam panci berisi air dan dimasak di atas nyala api, biarkan sampai mendidih lalu diangkat. Setelah suhu bahan mencapai $37^{\circ} \mathrm{C}$ tambahkan dengan $0,1 \mathrm{~g}$ pennicilin, $0,1 \mathrm{~g}$ streptomicin kemudian dihomogenkan;

(4) Masukan masing-masing 5\% (5g), 10\% (10g), 15\% (15g), 20\% (20g) kuning telur ke dalam campuran pengencer sehingga diperoleh 4 perlakuan. Tiap bahan perlakuan dimasukan ke dalam tabung reaksi kemudian dihomogenkan selama 5 menit dan ditutup dengan aluminium foil dan disimpan di dalam refrigerator;

(5) Endapan dari pengencer akan terbentuk setelah 2-3 jam penyimpanan. Supernatan dipisahkan dari endapan dengan menggunakan pipet; dan

(6) Setiap perlakuan diperiksa $\mathrm{pH}$-nya, $\mathrm{pH}$ pengencer yang baik berkisar 6,2 -6,8.

\section{Penampungan Semen}

Penampungan semen dilakukan dengan menggunakan vagina buatan pada temperatur yang stabil dan dilaksanakan antara pukul 07.30 - 10.00 pagi (WITA). Secara detail proses penampungan semen dijelaskan sebagai berikut. Penampungan semen diawali dengan mempersiapkan betina pemancing pada kandang jepit dan vagina buatan untuk menampung semen. Selanjutnya kambing jantan yang akan ditampung semennya diarahkan ke betina pemancing yang sudah siap dikandang penampungan semen. Pada saat kambing jantan mengalami ereksi, maka penis kambing tersebut diarahkan ke dalam tabung vagina buatan yang dikendalikan oleh seorang petugas. Vagina buatan dilengkapi dengan tabung sperma yang terbungkus rapi agar terlindung dari kontak langsunng dengan matahari. Semen yang sudah ditampung, selanjutnya di bawah ke laboratorium untuk dievaluasi.

\section{Evaluasi Semen Segar}

Evaluasi semen segar meliputi evaluasi secara makroskopik dan mikroskopik. Evaluasi makroskopik meliputi : volume, warna, bau dan ph. Sedangkan evaluasi secara mikroskopik meliputi: gerakan massa, konsentrasi, persentase motilitas, persentase spermatozoa hidup, persentase membran plasma utuh (MPU).

\section{Pengenceran Semen}

Semen segar yang telah dievaluasi dan layak untuk diproses lanjut diencerkan dengan tahapan sebagai berikut :

a. Penyediaan pengencer Tris-Kuning Telur Pengencer Tris-Kuning Telur dicampurkan dengan konsentrasi kuning telur yang berbeda-beda sesuai dengan perlakuan, yaitu 5\% (P1), 10\% (P2), $15 \%$ (P3) dan 20\% (P4).

b. Pengenceran semen

Semen diencerkan dengan terlebih dahulu mencampur semen dan Pengencer Tris-Kuning Telur dengan perbandingan 1:1. Campuran semen tersebut kemudian dimasukkan ke dalam kulkas untuk penyesuaian suhu. Selanjutnya semen tersebut ditambahkan pengencer Tris kuning telur sehingga konsentrasi $\begin{array}{lllll}\text { akhirnya menjadi } 100 & \text { x } & 10^{6}\end{array}$ spermatozoa $/ \mathrm{ml}$.

\section{Pemeriksaan Kualitas Semen Setelah Pengenceran}

Pemeriksaan kualitas semen setelah pengenceran hanya dilakukan secara mikroskopik meliputi : persentase motilitas dan persentase membran plasma utuh.

\section{Parameter yang diamati}

Parameter yang diamati pada penelitian ini adalah sebagai berikut :

a. Penilaian secara makroskopik meliputi : volume, warna, bau dan $\mathrm{pH}$ semen.

b. Penilaian secara mikroskopik meliputi : gerakan massa, konsentrasi spermatozoa, persentase motilitas, persentase membran plasma utuh. Sedangkan kualitas spermatozoa setelah pengenceran, pengamatan secara 
mikroskopis hanya terbatas pada persentase motilitas dan persentase membran plasma utuh.

a. Gerakan massa spermatozoa diketahui dengan cara membuat tetesan semen pada gelas obyek kemudian diamati dibawah mikroskop dengan menggunakan lensa obyektif 10X. Gerakan massa dikategorikan ke dalam tiga golongan, yaitu 1) pergerakan massa spermatozoa menyerupai awan tebal dan bergerak cepat $(+++), 2)$ pergerakan massa spermatozoa menyerupai awan tebal tetapi bergerak agak lambat $(++), 3)$ pergerakan massa spermatozoa menyerupai awan tipis dan bergerak lambat (+).

b. Evaluasi konsentrasi spermatozoa dilakukan dengan menggunakan haemocytometer dan evaluasi dilakukan di bawah mikroskop dengan menggunakan lensa obyektif 10x. Perhitungan dilakukan terhadap spermatozoa yang terdapat pada lima kotak teracak. Jumlah spermatozoa yang dihitung pada lima kotak tersebut (Sh) merupakan faktor yang dipergunakan dalam mengestimasi konsentrasi spermatozoa dengan menggunakan rumus (Hafez, 1987) sebagai berikut :

\section{KS = Sh $\times$ FM $\times P$}

Keterangan:

KS : kosentrasi spermatozoa

Sh : jumlah spermatozoa yang terhitung pada haemocytometer

FM : faktor multiplikasi

$\mathrm{P}$ : pengenceran

c. Persentase motilitas spermatozoa dapat diketahui dengan cara mengestimasi persentase spermatozoa yang bergerak progresif ke depan di bawah mikroskop dengan pembesaran 10x40. Skala penilaian berkisar antara $0 \%$ (tidak ada spermatozoa yang bergerak) sampai $100 \%$ (semua spermatozoa bergerak progresif ke depan). Penilaian persentase hidup spermatozoa dilakukan dengan menggunakan zat pewarna eosin. Sampel semen ditetaskan pada gelas obyek, ditambahkan satu tetas eosin dan dicampur secara homogen lalu dibuat preparat ulas. Preparat ulas tersebut dikeringkan di atas lampu bunsen dan selanjutnya dilakukan pengamatan di bawah mikroskop dengan pembesaran 10x40. Pengamatan dilakukan pada lima lapang pandang dan menghitung jumlah spermatozoa yang kepalanya berwarna merah dan yang tidak berwarna merah. Spermatozoa yang kepalanya berwarna merah digolongkan sebagai spermatozoa mati, sedangkan spermatozoa yang kepalanya tidak berwarnna merah digolongkan sebagai spermatozoa hidup. Persentasi hidup spermatozoa dihitung dengan menggunakan rumus sebagai berikut :

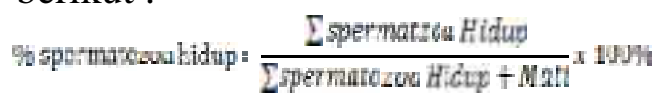

d. Persentase membran plasma utuh (MPU) diketahui dengan cara membuat larutan hipotonik ( $\mathrm{NaCl}$ 0,032 $\mathrm{M}$ dengan tekanan osmotik 53-63 m0smol/1) (Saili dkk. 2006). Evaluasi membran plasma spermatozoa yang utuh dilakukan dengan cara menghitung jumlah spermatozoa yang ekornya melingkar dan yang tidak melingkar. Spermatozoa yang ekornya melingkar dikategorikan sebagai spermatozoa yang membran plasmanya masih utuh, sedangkan spermatozoa yang ekornya tidak melingkar dikategorikan sebagai spermatozoa yang membran plasmanya tidak utu lagi. Evaluasi persentase membran plasma utuh dilakukan dengan menghitung jumlah spermatozoa pada lima lapang padang di bawah mikroskop, lalu ditentukan dengan menggunakan rumus :

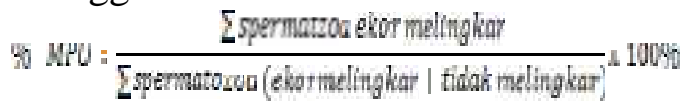

\section{Analisis Data}

Data hasil penelitian dianalisis menggunakan sidik ragam dan perbedaan antar perlakuan diuji menggunakan metode Uji Beda Nyata Terkecil/ BNT (Hanafiah, 2008). 
HASIL DAN PEMBAHASAN

A. Kualitas Semen Segar Kambing

Boerawa dan Kambing Kacang

Kualitas semen dan spermatozoa kambing Boerawa dan kambing Kacang yang dievaluasi meliputi kualitas makroskopis (volume, warna, bau dan $\mathrm{pH}$ ) dan mikroskopis (gerak massa, konsentrasi, persentase spermatozoa hidup, permentase

Tabel 5.1. Perbandingan Karakteristik Semen Kambing Boerawa dan kambing Kacang Secara Makroskopis motilitas, persentase keutuhan membran plasma).

\section{B. Evaluasi Semen Kambing secara Makroskopis}

Hasil evaluasi karakteristik semen kambing Boerawa dan kambing kambing Kacang secara makroskopis selama penelitian ditampilkan pada Tabel 5.1.

\begin{tabular}{lcc}
\hline \multirow{2}{*}{ Parameter } & \multicolumn{2}{c}{ Bangsa Kambing } \\
\cline { 2 - 3 } & Boerawa & Kacang \\
\hline Volume $(\mathrm{ml})$ & $1,86 \pm 0,55$ & $1,08 \pm 0,15$ \\
Warna & Krem & Krem \\
Bau & Khas & Khas \\
$\mathrm{pH}$ & $6,2 \pm 0,25$ & $6,4 \pm 0,26$ \\
\hline
\end{tabular}

\section{Volume Semen.}

Data pada Tabel 3 menunjukkan bahwa rataan volume semen kambing Boerawa adalah 1,86 ml/ejakulasi sedangkan rataan volume semen kambing Kacang sedikit lebih rendah yaitu $1,08 \mathrm{ml} /$ ejakulasi. Hasil ini sesuai dengan pendapat Pamungkas et al., (2008) bahwa volume semen segar kambing Boerawa dengan kambing Kacang yaitu 0,77-0,83 ml/ejakulat dan 0,69-1,03 ml/ejakulat (Hastonoet al., 2002). Beberapa laporan menunjukkan bahwa volume semen kambing Boerawa yaitu 0,69-1,03 ml/ejakulat (Hastonoet al., 2002) dan 0,53 $\pm 0,21 \mathrm{ml} /$ ejakulat (Mahmalia et al., 2006). Beragamnya volume semen ini selain dipengaruhi oleh perbedaan rumpun kambing, dapat pula dipengaruhi cara pengambilan, frekuensi penampungan dan umur kambing, berat, status kesehatan dan kualitas makanan (Setiadi et al., 2002).

\section{Warna Semen}

Hasil pemeriksaan makroskopis semen segar kambing Boerawa dan kambing Kacang menunjukkan warna putih krem, ini menunjukkan bahwa semen tersebut masih dalam kisaran normal. sesuai pendapat Gardner dan Hafez (2008) rata-rata warna semen yang baik adalah warna putih kekuningan atau krem jika berwarna hijau kekuning-kuningan berarti mengandung kuman pseudomonas aeruginosa, semen yang berwarna merah berarti mengandung darah dan semen yang berwarna coklat berarti semen tersebut mengandung darah yang telah membusuk. Warna semen pada penelitian ini sama dengan penelitian yang dilakukan oleh Triwulanningsih et al. (2013) dan Pamungkas et al. (2008) pada kambing adalah warna putih kekuningan (krem).

\section{E. Bau Semen}

Bau semen segar kambing Boerawa dan kambing Kacang pada saat penelitian didapatkan bahwa bau khas ternak. Bau tersebut menunjukkan semen tersebut dalam keadaan normal dan tidak terdapat kontaminasi. Semen dengan keadaan normal umumnya mempunyai bau yang khas disertai bau dari hewan tersebut. Sesuai dengan pendapat Kartasudjana (2001) yang menyebutkan bahwa semen normal umumnya memiliki bau yang khas dari hewan tersebut. apabila terdapat bau busuk menunjukkan semen bercampur dengan nanah.

\section{F. Derajat Keasaman (pH) Semen.}

Hasil pengamatan terhadap $\mathrm{pH}$ semen kambing Boerawa dan kambing Kacang adalah $6,2 \pm 0,25$ dan $6,4 \pm 0,26$. Dari data tersebut nilai derajat keasaman masih berada pada kisaran $\mathrm{pH}$ semen kambing yang 
normal yaitu 6,2-6,8 (Susilawati. 2011). Taringan (2004) menyatakan pH semen segar untuk kambing berkisar antara $\mathrm{pH}$ 5,97,3. Suyadi et al., (2004) menambahkan bahwa derajat keasaman $(\mathrm{pH})$ semen kambing Boer relatif normal yaitu berkisar antara 6,4-7,6.

\section{G. Evaluasi Semen Kambing secara Mikroskopis}

Perbandingan Karakteristik Semen Kambing Boerawa dan Kambing Kacang Secara MikroskopisDisajikan pada Tabel 5.2

Tabel 5.2. Perbandingan Karakteristik Semen Kambing Boerawa dan Kambing Kacang SecaraMikroskopis

\begin{tabular}{lcc}
\hline \multirow{2}{*}{ Parameter } & \multicolumn{2}{c}{ Bangsa Kambing } \\
\cline { 2 - 3 } & Boerawa & Kacang \\
\hline Gerakan Massa & +++ & +++ \\
Konsentrasi $(10 / \mathrm{ml})$ & $4,38 \pm 0,98$ & $4,52 \pm 0,12$ \\
Persentase Spermatozoa Hidup (\%) & $96,28 \pm 0,24$ & $93,43 \pm 1,20$ \\
Persentase Motilitas (\%) & $85,0 \pm 0,15$ & $85,0 \pm 1,40$ \\
Persentase MPU (\%) & $96,4 \pm 0,86$ & $95,1 \pm 0,42$
\end{tabular}

\section{H. Gerakan Massa.}

Gerakan massa memberikan gambaran tentang daya gerak spermatozoa secara massal yaitu semakin tebal dan besar gelombang serta pergerakannya semakin cepat menandakan kualitasnya baik (Tambing et al., 2000). Gerakan massa spermatozoa mempunyai kecenderungan untuk bergerak bersama-sama ke satu arah membentuk gelombang-gelombang yang tebal dan tipis, bergerak cepat atau lambat, tergantung konsentrasi spermatozoa hidup. Hasil pengamatan menunjukkan bahwa gerakan massa spermatozoa kambing Boerawa dan Kacang sama-sama mempunyai kualitas yang sangat baik $(+++)$.

\section{Konsentrasi.}

Hasil penelitian menunjukkan bahwa konsentrasi spermatozoa kambing Boerawa $\left(4,38 \times 10^{9} / \mathrm{ml}\right)$ sedikit lebih rendah dibandingkan dengan kambing Kacang $\left(4,52 \times 10^{9} / \mathrm{ml}\right)$. Hasil yang di peroleh tidak jauh berbeda dengan laporan Mahmilia et al., (2006) dan Hartono (2008) yang menyetakan bahwa konsentrasi spermatozoa kambing berturut-turut sebesar $2,58 \times 10^{9} /$ mldan $4,24 \times 10^{9} / \mathrm{ml}$. Perbedaan konsentrasi spermatozoa ini kemungkinan disebabkan oleh perbedaan rumpun kambing. Husin dkk. (2007) menyebutkan bahwa konsentrasi spermatozoa dipengaruhi oleh pakan, bangsa ternak, umur, suhu dan frekuensi ejakulasi.

\section{J. Persentase Spermatozoa Hidup.}

Persentase spematozoa hidup kambing Boerawa dan kambing Kacang yang diperoleh pada penelitian ini yaitu $96,28 \pm 0,24 \%$ dan $93,43 \pm 1,20 \%$. Hasil ini hampir sama dengan penemuan Hartono (2008) dengan persentase hidup sebesar 92,9\%, Demikian halnya dengan Husin dkk. (2007) menyebutkan bahwa nilai persentase spermatozoa hidup semen segar kambing Boer sebesar 83,64 $\pm 0,65 \%$. Persentase spermatozoa hidup merupakan salah satu parameter penentu kualitas semen karena dari persentase spermatozoa hidup dapat diketahuiberapa persen spermatozoa yang hidup. Nilai persentase spermatozoa hidup berhubungan erat dengan kemampuan fertilisasi spermatozoa. Bila nilai persentase spermatozoa hidup tinggi maka kemampuan fertilitas akan tinggi. Penentuan spermatozoa yang hidup dapat dilakukan dengan pewarnaan eosin negrosin, kemudian diamati menggunakanmikroskop perbesaran 400x. Bila semen dicampur dengan zat warna tersebut maka spermatozoa hidup tidak akan menyerap warna (Partodihardjo, 1992). 


\section{K. Persentase Motilitas.}

Hasil yang didapat pada penelitian untuk persentase motilitas spermatozoa kambing Boerawa adalah 85,0 $0,15 \%$, sedangkan kambing Kacang adalah $85,0 \pm 1,40 \%$. Hasil yang diperoleh tidak jauh berbeda dengan hasil penelitian Pamungkas et al., (2008) bahwa rataan persentase motilitas kambing kacang adalah $88,57 \pm 7,85 \%$ sedangkan kambing Boer sebesar $87,00 \pm 8,66 \%$. Motilitas individu sangat penting dilakukan untuk mengetahui kualitas semen segar. Motilitas tinggi akan memberikan peluang terjadinya fertilisasi lebih besar dibanding dengan semen motilitas rendah. Persentase spermatozoa motil yang bergerak progresif dapat digunakan sebagaiukuran kesanggupan untuk membuahi ovum (Setiadi dkk. 2002).

\section{Persentase Membran Plasma Utuh}

(MPU).

Kualitas spermatozoa juga dapat diukur dengan mengetahui keutuhan membran plasma. Hasil pemeriksaan MPU yang didapatkan pada kambing Boerawa adalah $96,4 \pm 0,86 \%$. Hasil tersebut tidak jauh berbeda dibandingkan dengan kambing
Kacang 95,1 $\pm 0,42 \%$. Penelitian ini jauh lebih baik dengan laporan Tambing et al., (2003) yaitu $82,40 \pm 5,08 \%$. Secara fisiologi terdapat hubungan antara membran plasma utuh dengan motilitas dan daya hidup spermatozoa. Apabila terjadi kerusakan pada membran plasma dapat menyebabkan hilangnya enzim-enzim yang diperlukan dalam proses metabolisme sehingga tidak dihasilkan energi sehingga motilitas menjadi rendah serta daya hidup juga rendah (Rizal et al., 2003). Beberapa hal yang dapat mempengaruhi perbedaan kualitas spermatozoa secara keseluruhan antara lain faktor individu, pakan, lingkungan, teknik dan frekuensi koleksi semen serta kondisi media pengencer di antaranya $\mathrm{pH}$ dan tekanan osmotik.

\section{Kualitas Spermatozoa Setelah Pengenceran}

1. Persentase Motilitas Spermatozoa Kambing Burawa Dan Kacang

Hasil pengamatan motilitas spermatozoa didapatkan rataan motilitas spermatozoa setelah diberi pengencer Tris Kuning Telur yang berbeda selama 4 hari. Seperti yang tercantum pada Tabel 5.3

Tabel 5. 3. Rataan Persentase Motilitas Spermatozoa Setelah Pengenceran (\%)

\begin{tabular}{ccccccc}
\hline \multirow{2}{*}{ Bangsa } & \multicolumn{9}{c}{ Pengencer Tris-Kuning Telur } & \multirow{2}{*}{ Rataan } & \multirow{2}{*}{ Total } \\
\cline { 2 - 5 } Kambing & $\mathbf{5 \%}$ & $\mathbf{1 0 \%}$ & $\mathbf{1 5 \%}$ & $\mathbf{2 0 \%}$ & & \\
\hline K1 & 82,02 & 83,97 & 84,15 & 83,49 & 83,41 & 333,63 \\
K2 & 83,67 & 84,87 & 86,73 & 84,23 & 84,88 & 339,50 \\
\hline Rataan & 82,85 & 84,42 & 85,44 & 83,86 & 84,14 & 84,47 \\
\hline Total & 165,69 & 168,84 & 170,88 & 167,72 & 168,28 & 673,13 \\
\hline
\end{tabular}

Hasil analisis ragam menunjukkan bahwa interaksi antara bangsa kambing dan konsentrasi pengencer Tris-Kuning Telur tidak berpengaruh $(\mathrm{P}>0,05)$ terhadap persentase motilitas spermatozoa setelah pengenceran. Rataan persentase motilitas spermatozoa tertinggi $(85,44 \%)$ diperoleh pada bangsa kambing Kacang dengan konsentrasi pengencer Tris-Kuning Telur $15 \%$. Sedangkan rataan persentase motilitas spermatozoa terendah $(82,02 \%)$ diperoleh pada kambing Boerawa dengan konsentrasi pengencer Tris-Kuning Telur 5\%. Rataan persentase motilitas spermatozoa kambing Kacang relatif lebih tinggi dibandingkan rataan persentase motilitas spermatozoa kambing Boerawa. Hal ini mungkin disebabkan oleh tingkat toleransi spermatozoa kambing kacang relatif lebih baik terhadap bahan pengencer Tris-Kuning telur dibandingkan dengan spermatozoa kambing Boerawa.

Motilitas kambing Boerawa dan kambing Kacang yang diperoleh pada penelitian ini masih dalam kisaran normal. Kartasudjana (2001) menyatakan bahwa 
spermatozoa yang memiliki motilitas kurang dari $60 \%$ tidak dianjurkan untuk digunakan dalam program inseminasi buatan. Berdasarkan pendapat tersebut maka hasil evaluasi motilitas spermatozoa pada beberapa konsentrasi berbeda masih layak untuk diproses lebih lanjut. Hal ini didukung oleh pendapat Susilawati (2011) yang menyatakan bahwa semen yang ditampung dan diuji kualitasnya, bila motilitas lebih dari $70 \%$ maka dapat diproses lebih lanjut.
Feradis (2010) menyatakan kebanyakan pejantan yang fertil mempunyai 50\% sampai $80 \%$ spermatozoa yang motil aktif progresif.

\section{Persentase MPU Spermatozoa} Kambing Boerawa dan Kambing Kacang Setelah Pengenceran

Hasil pengamatan persentase MPU spermatozoa kambing Boerawa dan kambing Kacang setelah pengenceran yang diperoleh pada penelitian ini tercantum pada Tabel 5.4.

Tabel 5.4. Rataan Persentase MPU Spermatozoa Setelah Pengenceran (\%)

\begin{tabular}{|c|c|c|c|c|c|c|}
\hline \multirow{2}{*}{$\begin{array}{c}\text { Bangsa } \\
\text { Kambing }\end{array}$} & \multicolumn{4}{|c|}{ Pengencer Tris-Kuning Telur } & \multirow{2}{*}{ Rataan } & \multirow{2}{*}{ Total } \\
\hline & $5 \%$ & $10 \%$ & $15 \%$ & $20 \%$ & & \\
\hline K1 & $63,24^{\mathrm{a}}$ & $62,74^{\mathrm{a}}$ & $63,13^{\mathrm{a}}$ & $63,10^{\mathrm{a}}$ & $63,05^{\mathrm{A}}$ & 252,21 \\
\hline K2 & $79,95^{\mathrm{ab}}$ & $86,37^{\mathrm{b}}$ & $92,69^{\mathrm{b}}$ & $87,22^{\mathrm{ab}}$ & $86,56^{\mathrm{A}}$ & 346,23 \\
\hline Rataan & $71,60^{\mathrm{A}}$ & $74,56^{\mathrm{A}}$ & $77,91^{\mathrm{A}}$ & $75,16^{\mathrm{A}}$ & 74,81 & 299,22 \\
\hline Total & 143,19 & 149,11 & 155,82 & 150,32 & 149,61 & 598,44 \\
\hline
\end{tabular}

3. Persentase Viabilitas Spermatozoa Kambing Boerawa dan Kambing Kacang Setelah Pengenceran
Hasil pengamatan persentase MPU spermatozoa kambing Boerawa dan kambing Kacang setelah pengenceran yang diperoleh pada penelitian ini tercantum pada Tabel 5.5.

Tabel 5.5. Rataan Persentase Viabilitas Spermatozoa Setelah Pengenceran (\%)

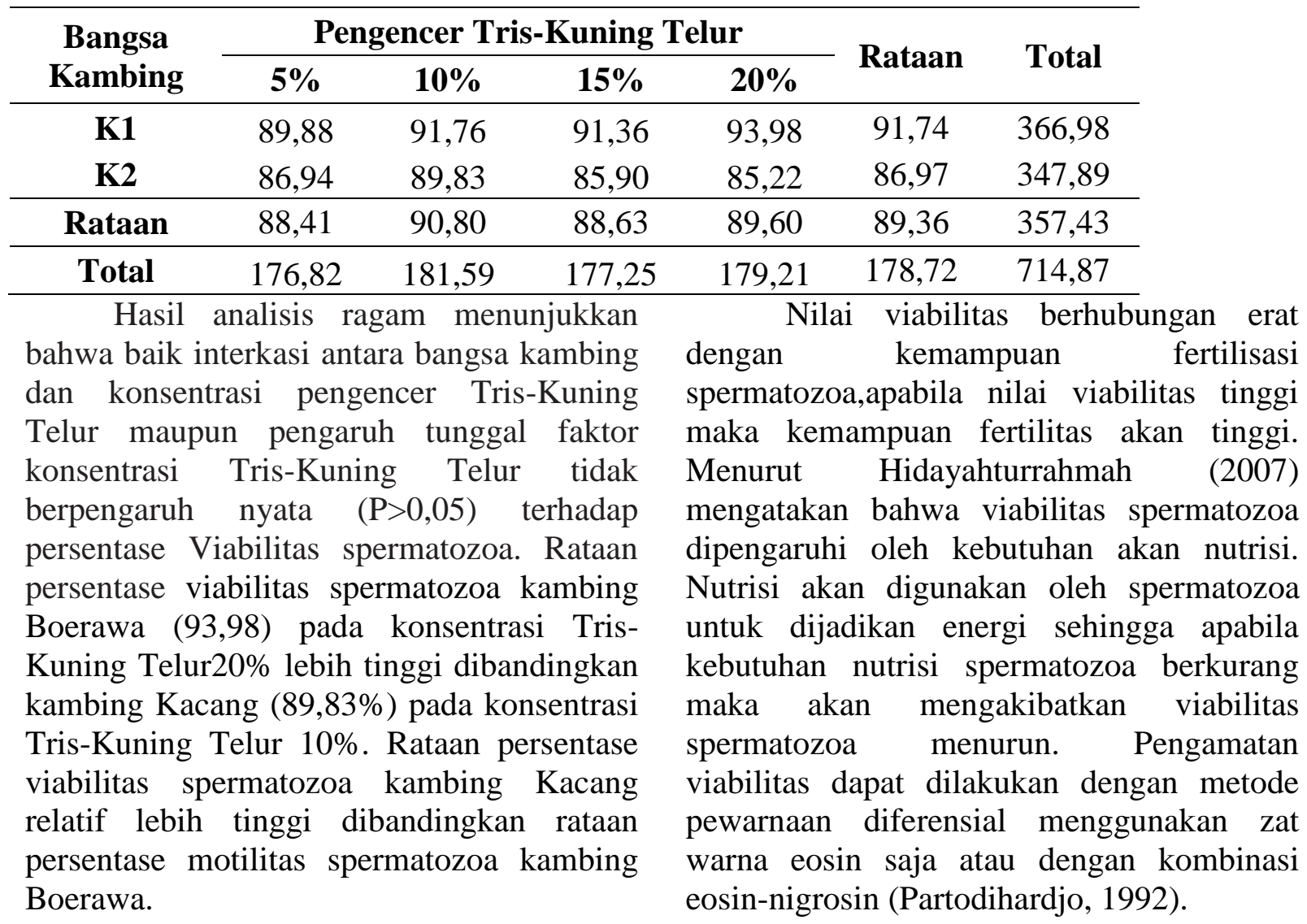


4. Perubahan Persentase Motilitas Spermatozoa Hasil Sexing Selama Penyimpanan

Evaluasi dilakukan empat hari berturut-turut untuk melihat pola penurunan motilitas spermatozoa selama penyimpanan di dalam lemari es $\left(3-5^{\circ} \mathrm{C}\right)$. Pola penurunan motilitas spermatozoa kambing Boerawa dan kambing Kacang selama penyimpanan disajikan pada Gambar 5.1.sedangkan persentase penurunan motilitasnya tercantum pada
Tabel
5.6.

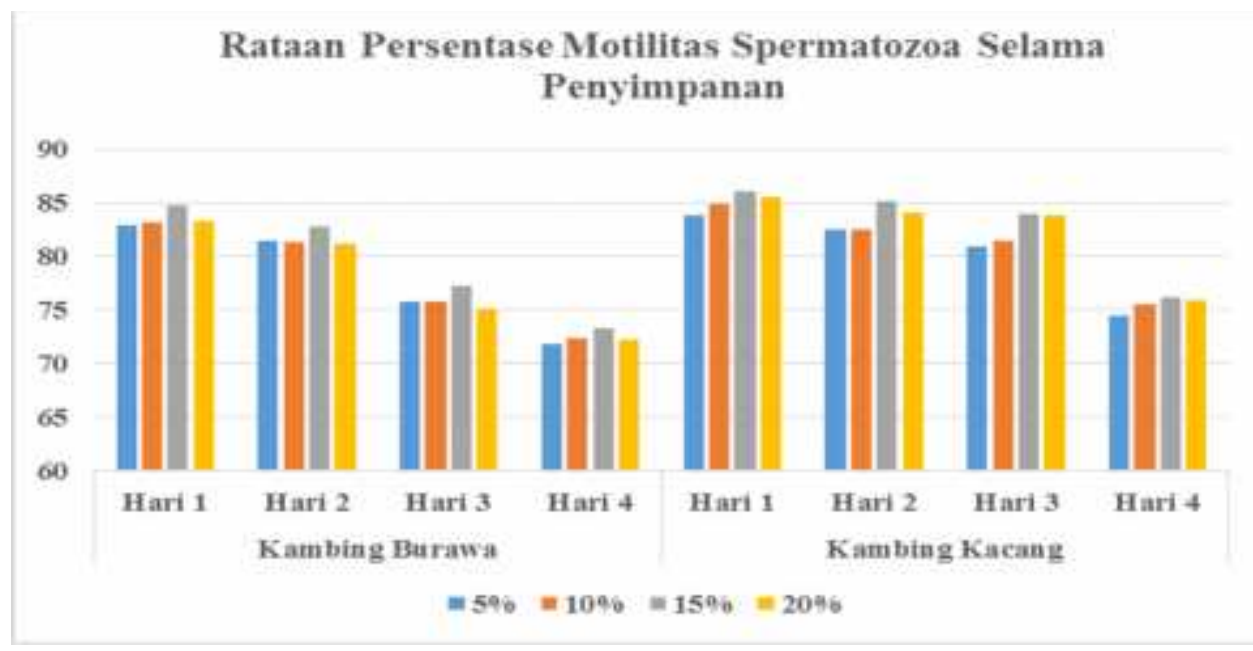

Gambar 5.1. Rataan Persentase Motilitas Spermatozoa Selama Penyimpanan

Tabel 5.6. Persentase Penurunan Motilitas Spermatozoa Kambing Boerawa dan Kambing Kacang Selama Penyimpanan (\%)

\begin{tabular}{|c|c|c|c|c|c|c|}
\hline \multirow{2}{*}{$\begin{array}{c}\text { Bangsa } \\
\text { Kambing }\end{array}$} & \multicolumn{4}{|c|}{ Pengencer Tris-Kuning Telur } & \multirow{2}{*}{ Rataan } & \multirow{2}{*}{ Total } \\
\hline & $5 \%$ & $10 \%$ & $15 \%$ & $20 \%$ & & \\
\hline K1 & 10,18 & 10,75 & 12,41 & 12,12 & 11,36 & 45,45 \\
\hline K2 & 7,98 & 8,81 & 9,51 & 8,28 & 8,64 & 34,58 \\
\hline Rataan & 9,08 & 9,78 & 10,96 & 10,20 & 10,00 & 10,23 \\
\hline Total & 18,16 & 19,56 & 21,92 & 20,40 & 20,01 & 80,03 \\
\hline
\end{tabular}

Persentase motilitas spermatozoa secara umum menurun dengan bertambahnya lama penyimpanan baik pada kambing Boerawa maupun kambing Kacang. Data pada Tabel 5.6. menunjukkan bahwa rataan persentase penurunan motilitas spermatozoa pada kambing Boerawa lebih tinggi $(11,36 \%)$ dibandingkan kambing Kacang (9,57\%). Sedangkan konsentrasi pengencer TrisKuning Telur yang mampu mempertahankan penurunan motilitas spermatozoa dengan nilai penurunan terendah $(9,08 \%)$ baik kambing Boerawa maupun kambing Kacang adalah konsentrasi pengencer $5 \%$ TrisKuning Telur.

\section{Perubahan Persentase MPU Spermatozoa Hasil Sexing Selama Penyimpanan \\ Evaluasi dilakukan empat hari} berturut-turut untuk melihat pola penurunan persentase MPU spermatozoa selama penyimpanan di dalam lemari es $\left(3-5^{\circ} \mathrm{C}\right)$. Pola penurunan MPU spermatozoa kambing Boerawa dan kambing Kacang selama penyimpanan disajikan pada Gambar 5.2., sedangkan persentase penurunan MPU-nya tercantum pada Tabel 5.7. 


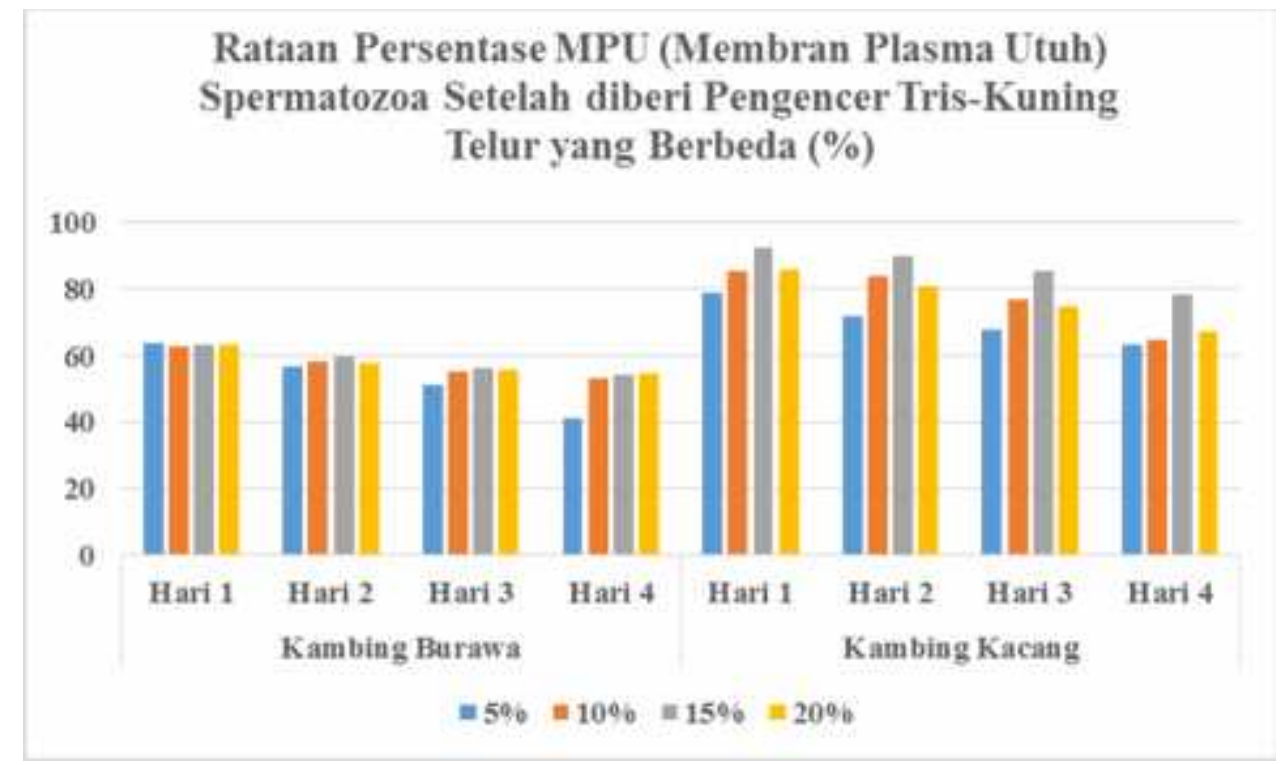

Gambar 5.2.Rataan Persentase MPU Spermatozoa Selama Penyimpanan

Tabel 5.7. Persentase Penurunan MPU Spermatozoa Kambing Boerawa dan Kambing Kacang Selama Penyimpanan (\%)

\begin{tabular}{|c|c|c|c|c|c|c|}
\hline \multirow{2}{*}{$\begin{array}{c}\text { Bangsa } \\
\text { Kambing }\end{array}$} & \multicolumn{4}{|c|}{ Pengencer Tris-Kuning Telur } & \multirow{2}{*}{ Rataan } & \multirow{2}{*}{ Total } \\
\hline & $5 \%$ & $10 \%$ & $15 \%$ & $20 \%$ & & \\
\hline K1 & 15,56 & 12,46 & 15,9 & 11,83 & 13,94 & 55,75 \\
\hline $\mathbf{K} 2$ & 14,57 & 13,50 & 17,48 & 16,0 & 15,46 & 61,85 \\
\hline Rataan & 15,07 & 12,98 & 16,69 & 14,07 & 14,70 & 14,61 \\
\hline Total & 30,13 & 25,96 & 33,38 & 28,13 & 29,40 & 117,60 \\
\hline
\end{tabular}

Persentase MPU spermatozoa secara umum menurun dengan bertambahnya lama penyimpanan. Data pada Tabel 5.7. menunjukkan bahwa rataan persentase penurunan MPU spermatozoa pada kambing Boerawa secara statistik lebih rendah (K1) $(13,94 \%)$ dibandingkan dengan persentase penurunan MPU spermatozoa kambing Kacang (K2) $(15,46 \%)$. Sedangkan konsentrasi pengencer Tris-Kuning Telur yang mampu mempertahankan penurunan MPU spermatozoa dengan nilai rataan penurunan terendah $(12,98 \%)$ baik kambing Boerawa maupun kambing Kacang adalah konsentrasi pengencer $10 \%$ Tris-Kuning Telur.

\section{Perubahan Persentase Viabilitas Spermatozoa Hasil Sexing Selama Penyimpanan}

Evaluasi dilakukan empat hari berturut-turut untuk melihat pola penurunan viabilitas spermatozoa selama penyimpanan di dalam lemari es $\left(3-5^{\circ} \mathrm{C}\right)$. Pola penurunan motilitas spermatozoa kambing Boerawa dan kambing Kacang selama penyimpanan disajikan pada Gambar 5.3. sedangkan persentase penurunan motilitasnya tercantum pada Tabel 5.8. 


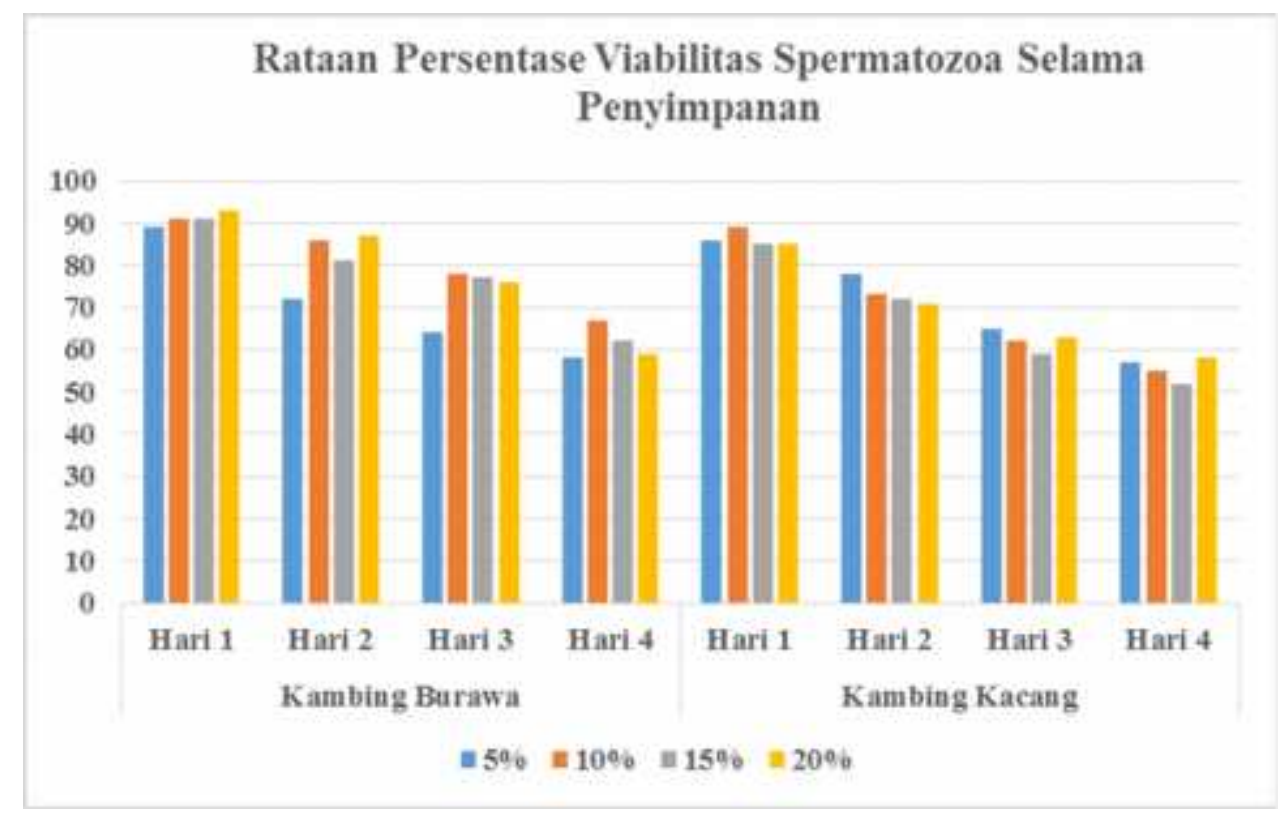

Gambar 5.3. Rataan Persentase Motilitas Spermatozoa Selama Penyimpanan

Tabel 5.8. Persentase Penurunan Motilitas Spermatozoa Kambing Boerawa dan Kambing Kacang Selama Penyimpanan (\%)

\begin{tabular}{|c|c|c|c|c|c|c|}
\hline \multirow{2}{*}{$\begin{array}{l}\text { Bangsa } \\
\text { Kambing }\end{array}$} & \multicolumn{4}{|c|}{ Pengencer Tris-Kuning Telur } & \multirow{2}{*}{ Rataan } & \multirow{2}{*}{ Total } \\
\hline & $5 \%$ & $10 \%$ & $15 \%$ & $20 \%$ & & \\
\hline K1 & 35.68 & 35.70 & 36.76 & 37.80 & 36.48 & 145.94 \\
\hline $\mathrm{K} 2$ & 34.15 & 43.14 & 41.51 & 44.96 & 40.94 & 163.76 \\
\hline Rataan & 34.91 & 39.42 & 39.14 & 41.38 & 38.71 & 39.66 \\
\hline Total & 69.83 & 78.84 & 78.27 & 82.76 & 77.42 & 309.70 \\
\hline
\end{tabular}

Persentase motilitas spermatozoa secara umum menurun dengan bertambahnya lama penyimpanan baik pada kambing Boerawa maupun kambing Kacang. Data pada Tabel 5.8. menunjukkan bahwa rataan persentase penurunan Viabilitas spermatozoa pada kambing Boerawa lebih rendah $(36,48 \%)$ dibandingkan kambing Kacang (40,94\%). Sedangkan konsentrasi pengencer TrisKuning Telur yang mampu mempertahankan penurunan viabilitas spermatozoa dengan nilai penurunan terendah $(34,91 \%)$ baik kambing Boerawa maupun kambing Kacang adalah konsentrasi pengencer $5 \%$ TrisKuning Telur.

Persentase MPU spermatozoa secara umum menurun dengan bertambahnya lama penyimpanan. Data pada Tabel 5.6. menunjukkan bahwa rataan persentase penurunan MPU spermatozoa pada kambing Boerawa (K1) (12,31\%) hampir sama dengan persentase penurunan MPU spermatozoa kambing Kacang (K2) (12,69\%). Sedangkan konsentrasi pengencer Tris-Kuning Telur yang mampu mempertahankan penurunan MPU spermatozoa dengan nilai rataan penurunan terendah $(6,53 \%)$ baik kambing Boerawa maupun kambing Kacang adalah konsentrasi pengencer $15 \%$ Tris-Kuning Telur. 


\section{KESIMPULAN}

Berdasarkan hasil dan pembahasan maka dapat disimpulkan sebagai berikut :

1. Karakteristik semen segar kambing Boerawa dan kambing Kacang menunjukkan kualitas yang hampir sama.

2. Interaksi perlakuan bangsa kambing dan konsentrasi pengencer Tris-Kuning Telur tidak berpengaruh nyata terhadap kualitas spermatozoa kambing.

3. Faktor konsentrasi pengencer TrisKuning Telur secara mandiri tidak berpengaruh nyata terhadap kualitas spermatozoa kambing.

4. Rataan persentase membran plasma utuh spermatozoa kambing Kacang nyata lebih baik dibandingkan kambing Boerawa setelah pengenceran.

5. Penurunan persentase motilitas spermatozoa selama 4 hari penyimpanan pada suhu $3-5^{\circ} \mathrm{C}$ lebih rendah pada kambing Kacang dibandingkan pada kambing Boerawa.

6. Konsentrasi pengencer Tris-Kuning Telur $10 \%$ mampu mempertahankan motilitas spermatozoa kambing lebih baik dibandingkan konsentrasi pengencer yang lain, sedangkan konsentrasi pengencer Tris-Kuning Telur 15\% mampu mempertahankan persentase MPU spermatozoa dibandingkan konsentrasi yang lain selama 4 hari penyimpanan pada suhu $3-5^{\circ} \mathrm{C}$.

\section{DAFTAR PUSTAKA}

Ariantie OS, Yusuf TL, Sajuthi D, Arifiantini RF. 2004. Kualitas Semen Cair Kambing Peranakan Etawah Dalam Modifikasi Pengencer Tris Dengan Trehalosa dan Rafinosa. Jurnal Veteriner 15 (1) : $111-22$.

Alawiyah, D dan M. Hartono. 2006. Pengaruh Penambahan Vitamin E Dalam Bahan Pengencer Sitrat Kuning Telur Terhadap Kualitas Semen Beku Kambing Boer.

Bergeron. A., M.H, Crete, Y. Bridle, and P, Manjunath. 2004. Low Density Lipoprotein Fraction from Hen's Egg York Decreases the Binding of the Major of Bovine Seminal Plasma to
Sperm and Prevents Lipid Efflux from the Sperm Membrane. Biol. Reprod 70:708-717.

Gardner.D.L., and E.S.E, Hafez. 2000. Spermatozoa and Seminal Plasma. Reproduction in Farm Animal. Hafez, B dan Hafez, E.S.E. $7^{\text {th }}$ ed. Lippincott Willims and Wilkins. Awollers Klitiwer Company. Philadelphia.

Hanafiah, K. 2008. Rancangan Percobaan Teori dan Aplikasi Ed.Revisi II Jakarta: Raja Grafindo Persada.

Hartono, M. 2008. Optimalisasi

Penambahan Vitamin E dalam

Pengencer Sitrat Kuning Telur untuk mempertahankan kualitas semen kambing Boer. Fakultas Pertanian Universitas Lampung, Bandar Lampung.

Hardijanto, Sardjito, T., Hernawati, T., Susilowati, T. Dan Suprayogi, TW. 2008. Penuntun Praktikum Fisiologi dan Teknologi Reproduksi (IB). Fakultas Kedokteran Hewan. Universitas Airlangga. Surabaya. P: 818.

Hafez, E.S.E. 2000. Reproduction in Farm Animal. 7th Edition. Lippincott Wlliams \& Wilkins. Maryland. USA.

Hastono, I.K. Sutama, P. Situmorang, I.G.M.

Budiarsana. T. Kostaman, U. Adiati, M.S. Hidayat dan Mulyawan. 2002. Pengaruh Intensitas Ejakulasi Terhadap Kualitas Semen Kambing Peranakan Etawah Dan Boer. Kumpulan Hasil-Hasil Penelitian APBN Tahun Anggaran 2001. Balai Penelitian Ternak Ciawi, Bogor. hlm. $181-190$

Husin et.al. 2007. Pengaruh Penambahan Pentoksifilin pada Pengencer Kambing Boer. Uhudabdullah. Blogspot.com. diakses tanggal 5 Juni 2015.

Kartasudjana, R. 2001. Teknik Inseminasi Buatan Pada Ternak. Jakarta.

Mahmilia, F., S. Elieser, M. Doloksaribu, F.A. Pamungkas dan M. Hutauruk. 2006. Karakteristik Produksi dan Reproduksi Kambing Boer pada Iklim 
Tropis basah. Laporan Akhir Kegiatan Penelitian PAATP 2006. Sumatera Utara.

Manjunath, P and I. Therien. 2002. Role of Seminal Plasma Phospholipid-binding Protein in Sperm Membran Lipid. Modication That Occurs During Capacitation Journal Reproduction Immunology. 53 : 109-119.

Pamungkas, F. A., Mahmilia dan S. Elieser. 2008. Perbandingan Karakteristik Semen Kambing Boer Dengan Kacang. Seminar Nasional Teknologi Peternakan dan Veteriner. Sungei Putih, Galang. Sumatera Utara.

Partodihardjo, S. 1992. Ilmu Reproduksi Hewan. Mutiara Sumber Widya, Jakarta.

Pramono, E. Dan Taswin R.T. 2008. Pengaruh Penambahan Adenosin Triphosphat ke dalam Pengencer Semen Terhadap Kualitas Spermatozoa Ekor Gemuk. J. Anim. Prod. 10 (3): 151 -156.

Putra, A.M., T. Susilawati dan N. Isnaini. 2012. Kualitas Proporsi Spermatozoa X dan Y Sapi Limousi Setelah Proses Sexing Menggunakan Gragien Densitas Albumin Putih Telur. Jurnal Peternakan. Malang: Universitas Brawijaya

Rizal. M., M.R Toelihere, T.L., Yusuf, B. Purwantara dan P. Sitomorang. 2003. Karakteristik Penampilan Reproduksi
Pejantan Domba Garut. JITV 8:134 140.

Setiadi,B.,Subandriyo, M.Martawidjaja, I.K. Sutama, U.Adiati,D.Yulistiani dan D Priyanto. 2002. Evaluasi Keunggulan Produktivitas Dan Pemantapan Kambing Persilangan. Kumpulan Hasil-Hasil Penelitian APBN Tahun Anggaran 2001. Balai Penelitian Ternak Ciawi, Bogor. hlm. 123 - 142.

Susilawati T. 2011. Spermatology. Universitas Brawijaya Press. Malang. Suyadi, Susilawati, T dan Isnaini, N. 2004. Uji Coba Produksi Semen Beku Kambing Boer. Laporan Penelitian. Fakultas peternakan.UB. Malang.

Tambing, S.N., M.R. Toelihere, T.L. Yusuf dan IK. Sutama. 2000. Motilitas daya Hidup Dan Tudung Akrosom Utuh Semen Kambing Peranakan Etawah Pada Berbagai Suhu Thawing. Pros. Seminar Nasional Peternakan dan Veteriner. Bogor, 18 - 19 Oktober 1999. Puslitbang Peternakan, Bogor.

Tarigan. 2004. Effect of Extenders and Cryoprotectants on Stallion Sperm Head Morphometry.

Toelihere, S.N. 1993. Inseminasi Buatan Pada Ternak. Angkasa Bandung.

Tarigan, A. 2004. Pengaruh Konsentrasi Tocopheral Yang Berbeda Dalam Pengencer Tris Aminomethane Kuning Telur terhadap kualitas semen kambing Boer. Fapet.ub.ac.id.uploads. 